\title{
ROSTIDADE TUPINAMBÁ: UM OLHAR DE ARTISTA PLÁSTICO
}

\author{
LithoSilva $^{1}$
}

\begin{abstract}
Resumo: Trata-se de uma reflexão sobre a importância da cultura indígena de matriz Tupinambá e da cultura Afro para a formação cultural local de Alagoinhas. Para tanto, traz treze arrotos antropofágicos para mostrar os elementos culturais da tradição indígena resistentes, como a produção do beiju e da tapioca, concluindo que o espírito Tupinambá está presente no coração guerreiro do cidadão trabalhador alagoinhense, o Alagoíndio.
\end{abstract}

Palavras-Chave: Cultura Tupinambá, Cultura Afro, Alagoinhas, Arrotos antropofágicos.

Summary: This is a reflection on the importance of indigenous culture Tupinambá matrix and the African culture to the local cultural training of Alagoinhas. To this end, brings thirteen belching anthropophagic to show the cultural elements of resistants of the indigenous tradition, such as the production of tapioca and of the tapioca, concluding that the Tupinambá spirit permeates the warrior heart of the alagoinhense worker citizen, the Alagoíndio.

Keywords: Tupinambá Culture, African Culture, Alagoinhas, Belching anthropophagic.

\section{PRIMEIRO ARROTO: UNIDADES RESISTENTES}

Entendo que Cultura é um grande armazém de símbolos e signos, e que os símbolos são sinais cujo valor é determinado pelo grupo e os signos são sinais que estão no lugar do real. A ciência dos símbolos e signos, a Semiótica, nos ensina que todo objeto é um signo, mas o valor do signo vai além do objeto. O valor interpretante do objeto depende do repertório do observador, que assim determina as construções das incertezas.

Os físicos quânticos revelam a possibilidade de que os Aborígines das ilhas Caribenhas, quando foram descobertas por Colombo, não avistavam as Caravelas, embora elas estivessem ancoradas próximas à praia. O Pajé, curioso com intenso movimento das águas em um único local, ficou horas observando que tipo de peixe estaria provocando tais movimentos. De repente, ele teria enxergado os navios e, assustado, revela para todos da sua comunidade. As-

1 Artista plástico de Alagoinhas, com exposições e premiações pelo mundo, há mais de 30 anos vem pesquisando a cultura e modos de vida indígenas, enfatizando a civilização tupinambá, onde se construiu uma sociedade sem senhor, nem obediência, como um valor permanente para a busca e exercício do homem livre. Adota os princípios da arte Kusiwa, que em tupi significa "o caminho dos riscos" e como pintor, através de pincéis e dedos, utiliza pigmentos naturais, carvão, argila, urucum, e, como escultor, o barro, o ferro e a pedra. Sua mirada e fonte de criação são as "unidades resistentes": a mandioca, e seus derivados, além de artefatos de fibra vegetal, presentes na sociedade contemporânea. Endereço eletrônico: lithosilvaarteindigena@gmail.com. 
Pontos de Interrogação, v. 4, n. 2, jul./dez. 2014

Revista do Programa de Pós-Graduação em Crítica Cultural

Universidade do Estado da Bahia (UNEB), Campus II - Alagoinhas — BA

sim, todos passam a enxergar os grandes navios. A princípio, por nunca terem visto tais objetos, a mente não reconhecia as imagens enviadas pelos olhos.

Alagoinhas é um grande armazém de fazeres, costumes e denominações de origem tupy e não são visíveis como elementos importantes da nossa cultura. A nossa mente ainda rejeita interpretar tais imagens. Por que será?

Os Portugueses determinaram que o litoral do Brasil fosse destinado ao plantio da cana de açúcar e o sertão à criação do gado. Alagoinhas está situada nos limites das duas zonas. Aqui foi plantada a cana de açúcar e o gado, vindo das torres do cruel Garcia D'Ávila, também bebeu das nossas fontes. Aqui, expulsaram as comunidades indígenas de suas terras por elas serem boas para o plantio do capim. Muitos morreram, outros foram levados e abandonados em áreas onde o plantio do capim era impossível.

O que vemos hoje é a pecuária dominando e destruindo as matas da nossa região, sinalizando que o cultivo da cana de açúcar encontrou sérias dificuldades que impediram o seu avanço na região. Assim, a presença do Afro na região não teve sustentabilidade, não teve tempo para deixar marcas nos costumes de viver da região; aqui vingou a criação de gado e outra mão-de-obra. Os senhorios precisavam de alguém que tivesse o domínio da caça e das matas e o sujeito naturalmente eleito foi o caboclo, ou o índio com o seu novo rótulo. Assim, surge a figura do vaqueiro. É bom lembrar que os índios não se alimentavam de carne bovina e nem de galinha, pois tinham esses animais como exóticos, que não deveriam ser devorados por não serem seus irmãos, razão pela qual não trariam uma boa sorte. Isso os tornava confiáveis para a tarefa de vaqueiro.

Aqui vivam os índios do tronco Jê, mas, por volta do ano 1000 da nossa era, chegaram os tupinambás e os expulsaram para dentro do sertão. Aqui eles plantaram, caçaram, vivenciaram grandes embates para conquistar a honra heroica e criaram uma psicosfera de fazeres que são vivas até os dias de hoje.

Chegaram também os Africanos, os Ingleses e os Franceses com as linhas do trem, trazendo o forte sentimento mercantil que, com o tempo, retiraram do repertório de todos os valores matrizes e recriaram novos elementos e eventos para preencher o vazio. Por sinal, continua existindo, pois há quem entenda que Alagoinhas não possui identidade cultural. 
O extermínio cultural em nossa cidade deixou sequelas profundas, mas ainda é fácil encontra as unidades resistentes da cultura tupinambá. Falta-nos a persistência do pajé para vêlas. Este tem sido o nosso propósito. Com a paixão da arte, havemos de enxergar e fazer enxergar cada vez mais os nossos símbolos matrizes.

\section{SEGUNDO ARROTO: OS PRIMEIROS}

Bula do Papa Paulo III, de 9 de julho de 1537, proclama os índios "verdadeiros homens e livres".

Os tupinambás aqui chegaram em busca da terra do "NÃO UM", a terra do "DOIS", onde a flecha traz a caça, onde o milho cresce sem a semente, onde a terra é a árvore e a árvore é a terra, onde o deus é o homem e o homem é deus. Andavam nus numa sociedade sem estado, sem senhor, sem obediência e igualitários viviam nas matas com seus mitos e seus heróis. Vieram, por certo, do alto da Amazônia, pois aqui plantaram a mandioca, a raiz que fora doada pelo herói Maíra. Um povo silvícola, extrativista e que amava seus filhos e todos os elementos da mata. Eram belicosos, vivam em disputa constante com outros grupos da sua própria etnia e tinham como maiores inimigos os tupiniquins. Quando os europeus aqui chegaram, foram recebidos com a saudação: Viestes!... Pois acreditavam que a terra do "não Um" era além do mar e eles eram os caraíbas da terra do "Dois".

Nesta terra, perto do litoral que hoje se chama Alagoinhas, encontraram tudo o que era necessário para sua sobrevivência: água limpa, argila e muita caça e peixes, e foi onde plantaram seus costumes de viver. O nosso povo da zona rural ainda planta em forma de jardim os mesmo elementos, processando-os da mesma forma, extraindo os mesmos produtos: a farinha, o beiju e a tapioca, com as mesmas tecnologias.

O cognitivo tupinambá ainda é vivo e estimula a resistência e a sobrevivência da cultura silvícola:

"Os Tupinambás propriamente ditos ocupavam a margem direita do rio S. Francisco até o Recôncavo Baiano". Seriam mais de 100 mil. Três traços principais marcavam este povo: a inteligência, a guerra e a abertura para o novo. Eram pessoas muito curiosas e observadoras. Um francês, Claude d'Abbville, que teve contato com o grupo tupinambá do Maranhão, escreveu: 'Imaginava que iria encontrar verdadeiros animais ferozes, homens selvagens e rudes, enganei-me totalmente. São grandes discursadores, possuem muito bom senso e so se deixam levar pela razão, jamais sem conhecimento de causas'. Constituíam o povo Tupi por excelência. As demais tribos 
eram, de certa forma, de sua descendência, embora o que de fato unisse e fosse a teia de uma inimizade crônica."

Hoje estão praticamente extintos, mas, se levarmos em conta o Mito dos deuses canibais que devoram seus guerreiros mortos e depois cospem seus ossos para ressurgirem imortais e sábios, eles estão vivos como o povo brasileiro, ou melhor, os Brasilíndios e, localmente, os Alagoíndios. Presente na luta da capoeira, nos cultos da Umbandha, na lida como o vaqueiro e nas lideranças revolucionárias, a exemplo de Lampião e de Antônio Conselheiro, temos hoje na política um presidente Caetés.

\section{TERCEIRO ARROTO: ROSTIDADE TUPINAMBÁ}

Os primeiros viam o outro não como espelho, e sim como devir. Quando estavam com o outro, ouviam mais que falavam, desejavam comer o melhor do mundo e do outro, o ser antropófago.

A metáfora da antropofagia é viva na construção cognitiva e social dos primeiros, do povo brasileiro e alagoinhense. O devir a ser, transforma-se com racionalidade no melhor para a sua sobrevivência, como um ser em si mesmo. Os Tupinambás chamavam de Caraíba aquele que dominava os dois universos: o sutil e o denso, que para eles é único. Não temiam a morte e não adoravam nenhum totem. Não tinham Deuses e nem senhores, e sim Heróis civilizadores, que os tratavam como iguais e riam deles. Possuíam três lideranças sem obediência: o Cacique, o Tuxaua e o Pajé. O cacique tinha que ter três qualidades: generosidade, poder da palavra e poder de pacificar. Ao tuxaua cabiam as estratégias e o comando nas batalhas. E ao Pajé cabia a proteção contra os maus espíritos, que traziam as doenças.

Era um povo silvícola. Vivam dos frutos da mata, da caça e da pesca. Igualitários, não acumulavam bens e não produziam artefatos para negociar, e sim para o uso próprio. Tinham uma sociedade sem estado, eram inteligentes e hábeis guerreiros, honravam a coragem e o herói como o grande matador. Viam o sofrer como necessário, porque constrói sonhos e os sonhos, o poder. O poder de transformar no Dois, eliminando o ego, o Um.

Hoje não temos o UM “O Tupinambá” entre nós, temos o Dois no povo do agreste do litoral norte da Bahia. Um novo tupinambá ressuscitado, o grande matador, transformando todas as culturas invasoras em algo especial e, com a sua alma livre, fazendo ressurgir a cultu- 
ra Afro na dança do forró; na luta da capoeira, com o seu arco-berimbau; nos Rituais dos elementais, a Umbanda; tendo as manifestações simbólicas dos caboclos sempre presentes nos cultos Afro de Alagoinhas e na figura do Vaqueiro que caça o boi na catinga com as habilidades de uma onça.

A antropofagia tupinambá constrói a cultura brasileira passo a passo. Aqui, tudo que cai se mistura e transforma-se em algo novo e especial e Alagoinhas não foge deste processo antropófago.

Em uma visita cuidadosa ao mercado onde acontece a grande feira semanal, podemos identificar as unidades resistentes:

A AMANDIOCA — Manihot esculenta

A MACAXEIRA — Manihot dulcis

A BATA DOCE - Ipomoea batatas

AS FAVAS - Phaseolus sp.

O AMENDOIM - Arachis Hypogaea

A ABÓBORA, O JERIMUM - Curcubita moschata

O ABACAXI, O ANANÁS — Ananás sativus

A BANANA DA TERRA - M. sapientum

O MARACUJÁ - Passifloras sp.

O CAJU - A nacardium

A PIMENTA — Capsium annu

O JENIPAPO — Genipa americana

O URUCUM - Bixa orellana

O TABACO - Nicotina tabacum

Todos ainda são cultivados em áreas pequenas com a mesma denominação de roça, processadas e degustadas nos mesmos costumes. É fácil encontrar as peneiras (urupembas) feitas de trissuma em grande quantidade, assim com as cestas, as vassouras de ouricuri. 
As ervas medicinas ainda são adotadas. Existem várias tendas vendendo e receitando-as e há muito mais. Basta querer contemplar para visualizar uma verdadeira comunidade tupi de forma ampliada e contemporanizada processando o costume de viver local.

No social, temos o político e o patrão na figura do Cacique com a obrigação de ser generoso, de realizar os desejos da sua comunidade e de pacificar os conflitos. Temos ainda as rezadeiras e benzedeiras, cuidando da proteção contra as doenças, dos maus espíritos e da má sorte.

Por fim, na festa anual da cidade de invenção alagoinhense, o Micarame ou Micarêta, são curiosamente ausentes os elementos de percussão, os tambores. A festa é animada por músicas estridentes que todos dançam construindo movimentos coordenados em grupo. Gritam e pulam, com muita bebedeira, como todos estivessem a celebrar uma vitória e um ritual antropofágico.

A rostidade tupinambá só é visível na nossa comunidade quando olhamos com os olhos da alma que sabe que tem um céu e uma terra. Somos um povo único com muitas misturas. Mas é preciso saber que o grande matador e o transformador cultural são os primeiros, os TUPIMANBÁS, principalmente aqui, nesta terra do Urupiara, protetor das pequenas lagoas, Upabamirins, Alagoinhas.

\section{QUARTO ARROTO: O ALAGOÍNDIO}

Darci Ribeiro, no seu livro O povo Brasileiro, cunha a expressão do Brasilíndio, referindo-se ao índio desaldeado que já perdeu os rituais e adotou os costumes Afro e Europeus, mas que mantém os traços da sua ancestralidade, embora tenha se tornado o outro.

O Alagoíndio é aquele cidadão euro-afro-índio que mantém os costumes do viver dos primeiros, os Tupinambás. Não mais possuem a cor, o cabelo e o porte físico da sua etnia. Agora, ele ou ela tem a pele parda, morena, escura e negra. Estranho é que todo individuo com pele mulata ou morena com nariz chato se autodenominam afrodescendentes. Somos afro-indígena descendentes. Até parece que criamos castas e o índio pertence à mais baixa delas. Assim descriminamos naturalmente a etnia raiz do povo brasileiro. O Alagoíndio não é $100 \%$ indígena, ele é afro, até por fazer parte da sua estrutura sociocognitiva a metáfora da 
antropofagia e do devir cultural, ou seja, o sentimento indígena é de não ver o outro como espelho, e sim o que se tornará amanhã.

A expressão Alagoíndio não exclui o Afro, ele está inserido no prefixo Alago, mas antes ela revela o que está esquecido: o índio na mistura. Se formos considerar os costumes de viver local, encontramos a predominância da cultura indígena desde o plantio estilo jardim das roças de mandioca, até o fazer da farinha, do beiju e da tapioca, processadas com as mesmas tecnologias. Na culinária, o pirão de peixe na folha de bananeira, o amendoim e as favas.

Temos ainda na produção silvícola: as urupembas, as cestas e as vassouras de vibras de ourucuri; a cerâmica modelada em forma de panelas, frigideiras e potes. Temos também as rezadeiras e os Caboclos nos cultos religiosos. No social, o modelo tupinambá é bem visível: no poder do arco, o do caçador, o homem; e no da cesta, a da produtora extrativista, a mulher.

Ainda hoje na zona rural as mulheres ficam em casa raspando a trissuma para fazer cesta e urupembas, e processado a mandioca, enquanto o homem vai caçar na cidade. Por não ter mais as matas, trabalham para poder cumprir o seu papel de trazer a carne, a caça amarrada a cipó para casa. Assim ele cumpre o ritual do poder do arco. Este inconsciente coletivo ainda é forte e influencia o Alagoíndio no seu dia a dia. Temos pouco tempo de colonização e de construção de um novo inconsciente. Muitos africanos foram albergados nas aldeias indígenas com o propósito de tamponar a cultura indígena.

O inconsciente africano não teve tempo suficiente para se revelar e dominar como um todo o no nosso campo das alagoinhas. $\mathrm{O}$ índio desapareceu da região, mas, como sujeito, ainda está presente. Venceu a antropofagia. O afro virou índio e o índio virou afro, mas só o desejo afro é visível. Não há nada de estranho se for utilizado o modelo civizilatório dos tupinambás, o do devir, o que tornar o Um no Dois, o poder do lagarto. À confirmação do dito do antropólogo Levi Strauss, quando ele esteve estudando a cultura Indígena: Não estamos diante de uma cultura primitiva, e sim de um novo modelo de civilização com uma nova ética e uma nova maneira de viver.

\section{QUINTO ARROTO: DIÁLOGO COM AS SOMBRAS}

O Seu João vende a meio século farinha na feira. É um homem alto de pele branca e de cabelos alvos como as farinhas que não cansa de elogiar: 
Pontos de Interrogação, v. 4, n. 2, jul./dez. 2014

Revista do Programa de Pós-Graduação em Crítica Cultural

Universidade do Estado da Bahia (UNEB), Campus II — Alagoinhas — BA

- Já mandei farinha para o mundo todo. Vem gente de todo lugar, não viajam sem a minha farinha. Alagoinhas possui a melhor farinha do mundo, pode acreditar.

- Mas por que ela é a melhor?

- Bem... A nossa farinha ainda é produzida à moda antiga. Ela é feita toda à mão, não tem máquina, não, ela é assada na pedra de barro à lenha... Prove esta aqui, foi queimada ainda ontem... Está quente... Veja.

— Tem gente que gosta desta fininha... Parece talco.

- Pois é... Eu gosto mais desta aqui, a mais grossa e redonda.

— Eu também, gosto de morder e sentir a textura da farinha. Está ótima. Dê-me um quilo.

- É bom levar da fina também, para fazer a farofa ela é boa.

— Tá bom, seu João, vou levar.

O seu João não está mais na feira, vende agora em casa.

A Mandioca é uma raiz venenosa. Contém cianureto se for comida crua pode causar paralisia ou a morte. Domesticada pelos tupinambás, ela é típica da região da Amazônia. Foi por eles trazida para esta faixa de terra entre o agreste e o Litoral Norte baiano, bem como para outras localidades do estado e do Nordeste. Esse fato demonstra um longo período de nomadismo. A mandioca conta a história da nossa gente bem mais que as aventuras ultramarinas. Ou melhor, essa é outra maneira de compreender a história, a nossa história. Contá-la na perspectiva do índio que estava aqui bem antes do português e do africano. Por isso, o alagoíndio se justifica sem negar as outras etnias e a sua importância.

Contam os mais velhos tupinambás que foi o herói civilizador Maíra quem deu a raiz e ensinou como processá-la para fazer a farinha, o beiju e outros derivados. Dela é também feita uma bebida chamada Cauim, é preparada pelas mulheres virgens, que põem na boca, mastigam e depois cospem em um pote para fermentar com a saliva. Bebem sempre na lua cheia todo o estoque.

Marta é uma jovem cabocla bonita, deve ter uns 24 anos. Tem uma linda cabeleira negra, cheia de trancinhas. A encontro sentada diante de um balaio de cipó, vendendo beiju de coco e de massa, mas não sinto alegria nela hoje. Por que será?

— Oi, Marta!!! Tudo bem com você?

- Acho que sim. Tenho hoje o beiju de massa. Vai querer?

— Não é com coco e açúcar, né?

— Não! É como você gosta, seco. Olhe aqui.

— Legal! Parece fresquinho, foi feito ontem?

- Claro. Você já sabe que lá no Catuzinho fazemos tudo de véspera.

- Como está a comunidade? Ela vai bem agora que foi reconhecida como quilombola?

— É, o pessoal está mais animado. Estamos aguardando as promessas chegarem.

- Diga, Marta, vocês vivem basicamente de quê?

- O pessoal planta mandioca para fazer a farinha, a tapioca e o beiju... Planta também uns pés de laranja e milho para o S. João, quando S. José manda chuva.

— Entendo, vocês tem um grupo de quadrilha, né? Você dança sempre.

— Já dancei no grupo do Buri. Hoje, tô noutra, sabe...? 
- Hum... tá amando.

— Deixa lá. Vai levar quantos pacotes hoje?

O Catuzinho é uma comunidade perto do Buri, acima de Sta. Terezinha. Uma região bonita, boa para umas caminhadas. Lá foi reconhecida como Quilombola, famílias de caboclos que se sentem afrodescendentes. O interessante é que os costumes e o modo de viver do grupo é basicamente tupinambá. Plantam em forma de jardim as mesmas raízes, e colhem o feijão de corda, o andu e o mangalô. Produzem nas casas de farinha os principais produtos de sobrevivência. Colhem nas capoeiras o maturi e o caju e, no Natal, os vendem na feira.

A Universidade de São Paulo realizou uma pesquisa de DNA em oito Quilombolas para ver a procedência étnica. Eles encontraram 51\% descendentes africanos, $48 \%$ de Ameríndio e $1 \%$ de outros. Dá para pensar.

Bertulina é uma Cabocla bem redondinha, tem uma cara amarrada mais muito engraçada quando se conquista a sua atenção, tem uns 70 anos e há muito deixou de fazer Urupemba por não poder ir à mata retirar a trissuma.

- Naquele tempo os caboclos limpos eram gente sem valor, viviam nas matas com os cabelos assanhados, muitas mulheres eram pegas no laço como a minha mãe.

- Os caboclos limpos. Quem eram? Eram índios?

- Acho que sim. Tinha um grupo que vivia em Igreja Nova, hoje Boa União, né? A terra era boa, aí chegaram os Senhores e expulsaram todos de lá e foram jogados aqui nos Portões e na Narandiba porque a terra não presta. Eles queriam as terras para criar gado, lá. Ficaram zanzando por aí, ninguém ligavam para eles. Viviam como bichos... Gente que não tinha valor para eles, como já disse.

— Com quem você aprendeu a fazer as peneiras?

- A urupemba aprendi com a minha mãe e ela aprendeu com a minha avó.

— Tem alguém marcante que você lembra em especial?

- Aqui tinha uma cabocla que pitava um cachimbo que nos levava para as matas para tirar a trissuma. Ela carrega uma peixeira nos quartos e não tinha medo de nada, nem dos bichos.

- Hoje poucas de nós tecem a Urupemba. Já estamos cansadas e estas meninas não querem saber de nada disto... sei não.

- Hoje em Alagoinhas existe ainda uma grande produção de urupembas, resultado do poder da cesta e do trabalho que reside nestas mulheres que enfrentam as matas, retiram a trissuma e trazem nos ombros em feixes. A trissuma é um junco, quando cortada fica a batata que faz brotar uma nova planta com novos ramos, após a primeira chuva.

A Urupemba é uma grande invenção tupinambá que resiste até hoje como elemento utilitário. É através desta atividade que muitas famílias da zona rural mantêm a sua economia próxima do saudável. 


\section{SEXTO ARROTO: UPABAMIRINS}

Alagoinhas teve a sua origem semelhante a das grandes cidades, às margens das águas, elemento essencial para a sobrevivência e a manutenção do bem estar.

Imaginem um cenário... Um campo rico de capim silvestre cheio de pequenos animais e de fontes de água doce banhando uma terra argilosa própria para confecção de louças de cerâmica, próximo da mata Atlântica e de clima estável. Um ambiente perfeito para caçar, plantar e para produzir artefatos utilitários, perfeito para uma sociedade silvícola os tupinambás.

Os tupinambás habitaram toda costa da Bahia. Como havia muitas disputas entre as próprias tribos para ficarem próximo ao mar, as vencidas eram obrigadas a procurar outras terras que garantissem as mesmas condições de sobrevivência.

Alagoinhas está localizada a $70 \mathrm{~km}$ do Litoral Norte e há $80 \mathrm{~km}$ do Recôncavo, áreas onde os tupinambás tinham uma forte presença. Em torno das lagoas plantaram pés de caju, jaqueiras e jenipapeiros. Nas capoeiras, plantaram a raiz domesticada, a mandioca, as favas e o amendoim. Da mata retiravam o cipó e a trissuma para confeccionar o arco e o cesto, símbolos da sua organização social. Tudo isto aconteceu anos atrás, durante um tempo quase infinito, tempo suficiente para criar uma identidade no ambiente, o que chamam os esotéricos de egrégora, o inconsciente coletivo. Hoje é fácil encontrar as unidades resistentes deste povo vivas em nossos costumes.

Na língua Tupy, Alagoinhas deveria ser chamada de Upabamirins, lagoas pequenas, seguindo o espírito adotado pelas cidades vizinhas como: Catu — bom, boa; Aramari — frutos; Irará - tira mel; Inhambupe — rio do Inhambu; Pojuca — pântano; e Araçás — goiabas.

Alagoinhas vive o sonho de que será feliz e próspera adotando os costumes do branco europeu.

\section{SÉTIMO ARROTO: ANTROPOFAGIA X CANIBALISMO}

Conta uma lenda entre os fulniôres, índios do tronco macro Jê do Nordeste, que um jovem guerreiro, hábil na caça e nas batalhas, gerava inveja aos demais companheiros da sua comunidade, ao ponto de planejarem a sua morte para absorver a sua força. Como pode tanta energia e sabedoria se concentrar num só homem? Não é justo, diziam eles. 
Assim, em uma noite escura, atacaram covardemente o jovem guerreiro e comeram a sua carne. Dias depois, morreram todos. Contam os mais velhos que a causa da morte dos covardes estava no fato de não perguntarem ao jovem herói de onde vinha a sua força e sabedoria. $\mathrm{O}$ ato praticado pelos covardes foi de canibalismo e não o da antropofagia, por não visarem à conquista do conhecimento, e sim a destruição e a eliminação do grande oponente.

Ensinam os mais velhos que não se deve destruir o inimigo, e sim a sua armadura da incompreensão, ou seja, o suposto inimigo geralmente se revela como um grande mestre para quem deseja o conhecimento, na vitória do matador ele absolve o saber do dominado.

A antropofagia é o ato de absolvição do saber que está no objeto fora de si, para tornar o ser mais criativo e sábio. Já o canibalismo é o ato emocional de domínio e eliminação do objeto fora de si, motivado pela incompreensão irresponsável, e torna o ser bruto ao absolver a massa do objeto dominado. A capacidade de eleger os objetos úteis e de unir às suas diversidades é a grande sabedoria do guerreiro matador. Destruir para realizar o novo, o criativo.

O conflito pode ser explodido ou implodido. Explodido gera a destruição; implodido, a criação. Por não termos dominado a sabedoria da compreensão, não estamos capacitados para resolver os problemas do outro e, nessa tentativa, construímos o mal e mais sofrimento patológico, e não aquele sofrimento que os sábios índios dizem que gera sonhos e poder.

A intolerância na diversidade gera a destruição do ser e do objeto incompreendido.

O grande desafio do guerreiro é de não perder a ternura, como dizia Che Guevara.

O grande desafio do guerreiro é de não se tornar reativo no combate. O convívio com o reativo, torna o ser canibal e não o antropofágico.

O ato antropofágico faz parte da cultura cristã e foi também adotado no Catolicismo. Quando o mestre Jesus, sabendo de sua morte, reuniu os seus discípulos, realiza o ato antropofágico, propondo na santa ceia: "Este é o meu corpo e este é o meu sangue”, referindo-se ao pão e ao vinho. Até hoje este ritual é celebrado entre os Católicos. Mas, aquele que não perguntar ao mestre de onde vem a sua sabedoria morrerá e o que perguntar, terá a vida eterna.

Outra lenda dos tupinambás, conta que os deuses devoram os guerreiros que morrem e cospem os seus ossos para então ressurgirem sábios e eternos. 
A metáfora da antropofagia está em várias culturas como na Índia, no Shiva, que é o elemento que representa a destruição e a criação, no Tao dos Chineses, no dois da Cabala e no devir dos Tupinambás.

A grandeza da antropofagia é celebrar o conflito e a diversidade para a construção da unicidade e o de combater o medo da morte. O guerreiro teme ser morto pelo jaguar e que os restos do seu corpo apodreçam na mata. Ser abatido pelo inimigo em um ritual onde se celebra a sua coragem e a sua valentia e de ter o corpo comido sem apodrecer é uma honra heroica, é o que faz sentido aos constantes embates dos guerreiros Tupinambás. Eu fico me perguntando: a nossa cidade Alagoinhas vive o processo antropofágico ou do canibalismo?

\section{OITAVO ARROTO: O CABOCLO ORIXÁ}

Na última visita ao Recôncavo Baiano, estive visitando, dessa vez tendo como guia um jovem descendente Afro, filho da cidade Cachoeira, o antigo prédio da prefeitura que fora no passado uma prisão. Tive então a oportunidade de questionar a ausência da cultura tupinambá na cidade, embora lá no pequeno museu estivessem três figuras em tamanho natural dos caboclos. O jovem iniciado responde com garbo que o negro fora mais presente na construção da cidade, embora os tupinambás tivessem participação na luta contra os Portugueses. Eles estavam ali como figuras religiosas e que os senhores europeus não tiveram a coragem de valorizar a participação do negro no conflito, um problema político justificável. Assim, o tupinambá tornou-se uma figura transcendente.

Participei de um encontro de culto afro em Alagoinhas, onde tive a oportunidade de realizar uma enquete com os dirigentes do Centro, para confirmar e entender uma afirmação, feita por de antropólogos alemães quando estiveram em nossa cidade estudando esses movimentos (eventos) religiosos, de que os cultos Afros na região de Alagoinhas tinham uma expressão particular.

Todos dirigentes de cultos Afros confirmaram a manifestação de Caboclos em seus rituais. Os caboclos pertencem a estrutura metafísica do culto da Umbanda que é uma religião brasileira, que tem na sua composição influências Afro, Indígena e católica.

Temos a Umbanda popular e a Umbanda Esotérica, sendo a última pouco conhecida e a que guarda mais as características da pajelança Ameríndia. W. W. Matta e Silva é o grande 
Sacerdote desta ordem esotérica e foi quem mais tentou desafricanizar a Umbanda, que tem a sua origem nos primórdios da nossa civilização.

No transcendente da nossa cidade temos a presença forte do cognitivo dos Tupinambás que não cultuavam espíritos, mas dialogavam com eles com muita naturalidade. Seus Pajés tinham o domínio sobre os espíritos do baixo astral e defendiam a comunidade de suas influências, enfrentando-os com a sua força anímica desenvolvida ao longo da sua existência. Eram escolhidos pelos mais antigos logo que nasciam através dos sinais físicos e psicofísicos. Realizavam um ritual conhecido por Pajelança, usando a maracá e o rolo e fumo, que acreditavam comunicar com o alto astral, e junto curavam e eliminavam a má sorte da caça e da guerra. A expressão Orixá, dizem eles que é a corruptela da palavra em Sânscrito "Purusha", que quer dizer centelha divina, essência, o homem.

A consciência nos seus sete níveis são os Chácaras. Então, os nomes destes centros de consciência é que levam os nomes dos Orixás, que para eles os principais são, com as corruptelas, os setes orixás: Yorimar, Oxossi, Ogum, Xangô, Iori, Iemanjá, Oxalá. Todos possuem uma assinatura, um grafismo próprio, conhecidos popularmente como pontos, que são vetores que indicam a elevação da energia telúrica de natureza nervosa e de manifestação sexual, a Kundalení com seus nós.

Assim, os Ameríndios processam a sua cosmologia rica de grafismos simbólicos que hoje é reconhecida pelo UNESCO como patrimônio imaterial da humanidade. A Arte Kusiwa, em Tupi, quer dizer o caminho dos riscos.

Alagoinhas esquece que é de Ogum pelo sincretismo, por ter como padroeiro o Santo Antônio, que lida com o fogo sagrado, resolve as grandes demandas, tem como o estômago o centro absolvição das emoções e um bom apreciador dos bons alimentos.

Um perfeito antropófago cultural.

Salve Upabamirins! Salve Alagoinhas! Salve Ogum! Salve Santo Antônio!

\section{NONO ARROTO: CENOGRAFIA PARA UM ESTRANHO MEDO}

Carregamos dentro de cada um de nós brasileiros um estranho medo de revelarmos ao mundo, através de palavras e atitudes, a nossa descendência Tupinambá. Talvez por uma de- 
fesa, o inconsciente mantenha este medo, o de ser eliminado. Sabemos que o medo pode ser implodido ou explodido. Implodido vira atenção, já foi o tempo; e explodido, pavor. O pavor de hoje é o que somos e somos obrigados a aceitar este medo ruim. Conduzimos, aprisionados nas gaiolas das nossas almas, os sentimentos como o "sorriso contente", "a confiança" e outros afins. Deveríamos libertá-los das nossas gaiolas, para adornar com seus cânticos e desempenho as nossas atitudes. Usá-los como usamos os produtos de consumo no abuso. Caso contrário, eles é que irão nos usar e nos devorar.

Pelo quadro social que vivenciamos hoje, não é estranho afirmamos que já estamos neste processo do medo que devora a autofagia nas dores com seus efeitos, como não identificamos as razões estéticas dos nossos desejos: o de não termos um senhor, de não termos obediência a nada e o de não querer acumular bens, mas o de termos o direito de obtê-los, incluindo o direito à autossuficiência.

O cognitivo do povo brasileiro tem a rosteidade tupinambá, ou seja, com seu valor metafísico, do "não um", que vê o outro não como espelho, mas o seu devir; e o da metáfora da antropofagia, o desejo de devorar o melhor do mundo. O querer conceber uma cenografia com objetos interpretantes para que os sujeitos possam perambular pelo palco do seu cotidiano e sejam estimulados a implodir o medo da sua descendência indígena, ousar ser brasileiro e, sem medo, ser o Alagoíndio.

\section{DÉCIMO ARROTO: O AÇOUGUE}

"Aqui chegaste e trabalhais tanto para amontoar riquezas para os vossos filhos ou para aqueles que vos sobrevivem! Não será a terra que vos nutriu suficiente para alimentá-los também X Temos pais, mães e filhos a quem amamos, mas estamos certos de que, depois de nossa morte, a terra que nos nutriu também os nutrirá, por isso descansamos sem maiores cuidados." (Discurso de um tupinambá anotado por Jean de Lery, Rio de Janeiro, 1558).

Em nome do progresso, abatemos prédios que são verdadeiros monumentos da história estética e cultural da nossa cidade e, com a mesma atitude que compramos a carne no açougue, levamos para o futuro uma ausência de valores significativos.

Quando voltamos do açougue com o fardo de carne para casa, não temos consciência do que compramos, julgamos estar levando um produto manufaturado e não um pedaço de um corpo cuja vida fora ceifada brutal e desnecessariamente, por já termos nos dias de hoje outras 
opções para nos alimentar. Tudo é justificável e racional para todos ou quase todos e assim construímos atitudes e hábitos que, sem percebermos, um dia irão nos consumir.

Retornando ao patrimônio material da cidade, há quem pense que quem gosta de coisas velhas é o museu, como se o museu fosse um depósito de elementos inúteis para a construção humana.

Autofagia é um processo que se instala por falta de atitudes para consigo e para com os outros. A ferrugem se instala nos metais mais resistentes da mesma forma. Precisamos valorizar as matrizes como bases para realizar o novo que um dia será velho e cheio de informações do seu tempo, que será inspiração para as novas construções.

Um corpo não sobrevive sem a memória, ou seja, sem referência de identidade perde-se o sentido de existir. Como a ferrugem consome o duro corpo de metal por falta de atenção, uma comunidade se devora por falta de identidade como a loucura pela perda do domínio da razão estética. Assim com um vegetariano tem dificuldade de digerir um cadáver de um animal, um filho da terra terá as mesmas dificuldades de digerir as justificativas e as dores causadas pela queda de cada tijolo e de cada telha da nossa história.

\section{DÉCIMO PRIMEIRO ARROTO: O BEM NÃO EXISTE, ELE TEM QUE SER CONSTRUÍDO}

A origem deste conhecimento partiu de uma conversa com um velho xamã...

— Você tem que entender a natureza do mal e do bem para lidar com a magia da vida... Medite.

Bem... Depois de refletir e desenvolver a atenção nas informações selecionadas, percebo que o bem é um processo e não um estado, como fora ensinado pelos meus "professores". A importância desta descoberta para mim foi de grande valia.

Como processo, o bem não se instala, ele reflete como um flash e, para ser classificado como o bem no sentido amplo da palavra, o seu brilho tem que banhar a todos e não a poucos. O Mal é também o Bem mal feito. Por isso, realizar o Bem é realizar um MILAGRE. E milagres não existem... Mas têm que tentar realizá-los ou construí-los, não é verdade? 
O impulso é expressar: se o bem não existe, o mal também não existe. Pensando bem, você começa a perceber que a questão dos opostos no ocidente não é bem resolvida, ou melhor, não é bem entendida. Temos um sinal para quem está atento. O símbolo na matemática do negativo é um pequeno traço horizontal [-] e o positivo seguindo a lógica ocidental do oposto seria um traço vertical [I], mas não, ele é uma pequena cruz [+]. O que colhemos desta informação? Que o positivo que é simbolicamente o bem, só é visível com a presença do negativo que é simbolicamente o mal, do pequeno traço horizontal. Marginalizamos o mal, mas ele é o elemento provocador para o ser construir o bem. Surge um pensamento aterrador: a essência da natureza da vida é o mal. Sim, ele é o elemento provocador para o Ser reagir ao incomodo e criar o bem. Outro pensamento surge... Mas a natureza não é perfeita, não é o bem se manifestando.

Importante é perceber que o visível não é o perfeito e sim o invisível... da natureza... $\mathrm{Na}$ prática, basta um descuido e o incomodo se instala no Ser em forma de doença e dores. Gostaria de lembrar o conceito de que é a verdade igual (=) a perfeito e do conceito que adoto: verdade é tudo aquilo que é importante para o ser.

A nossa dificuldade é eleger o elemento e o ponto de importância do Ser ou o do observador.

Na filosofia Hindu, encontramos o ponto de vista Sankhya que nos ensina os comportamentos dos dois elementos matriz da vida a força e o poder. Revela que a força pode atuar sem o poder, mas o poder não pode se manifestar sem a força.

Quando a força se manifesta sem o poder, ela cria desordem, incômodo e dores e é o que classificamos como o mal. A força é visível, o poder é invisível. Ele só pode ser percebido através da manifestação da força como hospedeira do poder. Quanto maior for a presença do poder na ação, o movimento [força + poder] construirá a ordem, o que classificamos com o bem.

O cara que matou Deus (Nietzsche) fala dos dois elementos como: O reativo [a força] e o ativo [o poder] que seguem os princípios similares, mas não tão ricos como os da filosofia Hindu. Encontramos nos mitos Tupinambás pontos de vista similares quando falam da terra sem o UM a terra do DOIS, onde a harmonia e a felicidade é uma realidade. Eles resistem às 
Pontos de Interrogação, v. 4, n. 2, jul./dez. 2014

Revista do Programa de Pós-Graduação em Crítica Cultural

Universidade do Estado da Bahia (UNEB), Campus II — Alagoinhas — BA

dores porque sabem que estão na dimensão do UM, ou seja, estão na terra de um homem e de uma mulher, na terra do rio, da montanha, separados.

$\mathrm{Na}$ terra do Dois existe rio montanha, montanha rio e o homem mulher e a mulher homem e um deus homem e o homem deus. Percebemos o sentido do símbolo matemático do positivo composto por dois traços.

O bem é o Dois: poder e força - ativo e reativo. O mal é o Um, ou é a força ou é o reativo manifestando sem ser hospedeiro do poder, ou seja, sem ser o Dois. Isto é antropofágico.

Alagoinhas se caracteriza como um elemento reativo, reativo para com seus heróis, filhos que não são reconhecidos com seus feitos, com seus símbolos matrizes e com seus monumentos arquitetônicos. Não manifestamos com clareza o amor pela cidade, não temos o bairrismo, nos classificamos como "sem identidade cultural”. Os filhos não desejam permanecer e criar os seus filhos aqui. O momento pede a construção do BEM, do DOIS no nosso meio e cabem aos mais velhos filhos desta terra Upabamirns construir o KATU, o BEM. Unir o passado com o presente, os valores antropológico com os institucionais e o mitológico cultural com o religioso. E poder gritar e ter o prazer de ouvir: Sou filho de Alagoinhas!

\section{DÉCIMO SEGUNDO ARROTO: HISTÓRIA E VERDADE}

Ouvi falar que uma mentira contada com determinação durante dezenas de anos vira uma verdade. O que leva uma mentira a virar uma verdade? Imagino que seja a necessidade que cada um tem de eleger um ponto de importância no seu emocional, no seu físico e no social para se proteger e garantir a sua sobrevivência, como a esperança.

A história como esperança revela a existência de um sofrimento. Os Tupinambás tem uma máxima que diz que o sofrimento gera sonho e o sonho gera o poder. A história sem a verdade gera no sujeito a autofagia, um sofrer sem sonhos.

A verdade... Aceito como Verdade tudo aquilo que é importante. Como cada sujeito tem seus pontos de importâncias, então variam as verdades e os conflitos. Seres sociais que somos, construímos pilares de importâncias comuns ou verdades: o mitológico, o racional e o biológico. Infelizmente, os pilares mais valorizados são: o mitológico e o racional. Com isso, o sujeito perde a auto-suficiência, o foco, a consciência de si mesmo. 
Observando uma criança no seu ato de respirar, notamos que ela dilata a parte baixa do abdômen, mas quando ela cresce e vira adulto esquece este saber inato e passa a respirar dilatando a parte alta do seu abdome, alterando o seu biorritmo natural. Fazendo analogia para com a verdade, nascemos com o biológico de respirar, de se alimentar, de pensar criativo e de procriar com prazer. Com o tempo os outros pilares destroem estes valores pouco a pouco, o sexo com o mito do pecado, o pensar com a razão e com a política dos valores que instala a consciência de manada que mais tarde estragam os alimentos, o ar, a história e a verdade.

Uma história e uma verdade é um devir, tem que ser sempre recontada e avaliada, buscando a consciência, valorizando o inconsciente coletivo, o egrégora produtivo e a estética. Pensar uma história a partir da estética de um egrégora e de um inconsciente coletivo é valorizar a etimologia e a analogia, é ficar próximo do biológico, do viver natural. E este é o nosso sentimento para com a nossa história, a história de Alagoinhas, sem mistérios e sem denominação.

\section{DÉCIMO TERCEIRO ARROTO: O TRABALHO, O EMBATE E A CRIAÇÃO}

A expressão de que o trabalho é o responsável pela riqueza e a ela tem que retornar, deixa um problema: uma ação do trabalhador por si só não constrói riqueza, por exemplo: ações como de um grupo esvaziando um rio com baldes ou escavando um buraco no deserto, por certo não trarão riquezas, porque falta uma ideia, ou melhor, falta o idealizador, o criador para justificá-la, como ação produtora de riquezas. O idealizador é o empreendedor, o sujeito que irá dar sentido à ação do trabalhador. A ideia torna-se matriz da riqueza.

Portanto, vejo perigo ao negar o valor do empreendedor, em negar o direito e a importância no grupo do sujeito criativo e da sua responsabilidade pelo sucesso do trabalho ou da ideia multiplicada. Construir uma casa sem o saber e sem a criação não resultará em um objeto de riqueza.

O artista e o artesão que roteiros teriam, nesta perspectiva de que o trabalhador é o responsável pelo resultado da riqueza e não a sua ideia criativa? Como distribuir a riqueza conquistada? Os direitos autorais, como se firmariam? Como se construiriam as lideranças? A criação é mais importante que o criador? 
Imaginem uma sociedade sem estado, sem senhor, sem obediências e igualitária. Perfeito, não? O sonho de todo jovem revolucionário. Ela existiu aqui neste platô chamado Brasil e assim viviam os primeiros, os Tupinambás. Os Portugueses ficaram extasiados e depois enfurecidos. Não encontraram um rei para realizar acordos, subornos e outras falcatruas. Encontram uma civilização com uma nova ética, com uma nova maneira de viver.

Não adoravam Deuses, nem eram idólatras. Não acumulavam bens, nem possuíam mercados e economia. A natureza provia tudo e todos viviam como os pássaros. Guerreavam entre si, não para conquistar territórios ou bens, mas pelo ato heroico de ser e de celebrar a morte. Degustavam os seus heróis inimigos para absolver o melhor e, ao herói degustado, sobrava o conforto de saber que seu corpo não iria apodrecer no tempo.

O Trabalho e a caça, duas atividades que o antropólogo francês Pierre Clastres denominou de poder da cesta e do arco, que marcavam a organização social dos primeiros: o trabalhar a terra cabia às mulheres; a caça e a guerra aos homens. Hoje não temos mais os embates e a caça, o homem perdeu a posição heroica do guerreiro e tornou-se o humilde trabalhador.

Só temos quinhentos anos de mudanças radicais de comportamento civilizatório. $\mathrm{O}$ inconsciente coletivo continua basicamente o mesmo e o cognitivo do guerreiro ainda é vivo no cidadão alagoinhense, o Alagoíndio.

Visível entre os nossos, a existência do conflito: Trabalho, senhor e política.

Trabalho, a posição humilde que incomoda ao ex-guerreiro sem a oportunidade de construir a honra heroica. Temos o abuso das reclamações trabalhista na cidade.

Na política, todos aqueles que se candidataram ao cargo de Prefeito do município, que adotaram a postura de Senhor, foram reprovado pela comunidade, sempre eleito o candidato mais humilde e com atitudes heroicas. A cidade sempre teve a postura de não obediência às imposições políticas, manifestando a tendência ao socialismo e ao comunismo social.

O espírito tupinambá, o de ser igualitário e solidário ao coração guerreiro, influenciando a identidade política da cidade.

Há dentro de cada um de nós um guerreiro,

Em forma de coração.

O coração guerreiro,

Ele sabe que não existe um inimigo a ser destruído.

E sim, a armadura da incompreensão.

Ele sabe que o desejo é a busca do caminho. 
Ele sabe que a paixão é encontra o caminho.

O amor é a tensão para permanecer no caminho.

E o bem é chegar e tornar-se o caminho.

Como artista e filho desta terra, desejo realizar o ato heroico de ver e fazer ver o grande barco ancorado nas nossas praias, de acreditar e fazer acreditar que ele veio da terra do não UM. Então, praticar o escambo com os nossos ancestrais para adquirir o necessário para a construção da nova e verdadeira ética para consigo e para com o próximo. Desse modo, tornar o DOIS.

Katu!

Recebido em: 19 de outubro de 2014.

Aceito em: 20 de novembro de 2014. 